\title{
Antigen Gene
}

National Cancer Institute

\section{Source}

National Cancer Institute. Antigen Gene. NCI Thesaurus. Code C54259.

A gene that encodes a product, termed an antigen, which stimulates the immune system and results in the production of antibodies. 